\title{
Technical Specifications of Structural Health Monitoring for Highway Bridges: New Chinese Structural Health Monitoring Code
}

\author{
Fernando Moreu ${ }^{1,2 *}$, Xiaomeng Li ${ }^{1}$, Shunlong $\mathrm{Li}^{3}$ and Dongyu Zhang ${ }^{4}$ \\ ${ }^{1}$ Department of Civil Engineering, University of New Mexico, Albuquerque, NM, United States, ${ }^{2}$ Department of Electrical and \\ Computer Engineering, University of New Mexico, Albuquerque, NM, United States, ${ }^{3}$ Department of Bridge and Tunnel \\ Engineering, School of Transportation Science and Engineering, Harbin Institute of Technology, Harbin, China, ${ }^{4}$ School of \\ Civil Engineering, Harbin Institute of Technology, Harbin, China
}

\section{OPEN ACCESS}

Edited by:

Eleni N. Chatzi,

ETH Zurich, Switzerland

Reviewed by:

Jiazeng Shan,

Tongji University, China

Maria Pina Limongelli,

Politecnico di Milano, Italy

*Correspondence:

Fernando Moreu

fmoreu@unm.edu

Specialty section: This article was submitted to

Structural Sensing,

a section of the journal

Frontiers in Built Environment

Received: 26 October 2017 Accepted: 02 February 2018

Published: 01 March 2018

Citation:

Moreu F, Li X, Li S and Zhang D (2018) Technical Specifications of

Structural Health Monitoring for

Highway Bridges: New Chinese Structural Health Monitoring Code.

Front. Built Environ. 4:10.

doi: 10.3389/fbuil.2018.00010
Governments and professional groups related to civil engineering write and publish standards and codes to protect the safety of critical infrastructure. In recent decades, countries have developed codes and standards for structural health monitoring (SHM). During this same period, rapid growth in the Chinese economy has led to massive development of civil engineering infrastructure design and construction projects. In 2016, the Ministry of Transportation of the People's Republic of China published a new design code for SHM systems for large highway bridges. This document is the first technical SHM code by a national government that enforces sensor installation on highway bridges. This paper summarizes the existing international technical SHM codes for various countries and compares them with the new SHM code required by the Chinese Ministry of Transportation. This paper outlines the contents of the new Chinese SHM code and explains its relevance for the safety and management of large bridges in China, introducing key definitions of the Chinese-United States SHM vocabulary and their technical significance. Finally, this paper discusses the implications for the design and implementation of a future SHM codes, with suggestions for similar efforts in United States and other countries.

Keywords: structural engineering, highway bridges, codes of practice and standards, bridge maintenance, sensors

\section{INTRODUCTION}

Civil Engineering standards and codes are designed to ensure the safety of infrastructure and surrounding populations (Lynch and Loh, 2006). Therefore, governments must regulate the design, construction, and maintenance of structures, including buildings and bridges. In this regard, governments, societies, institutions, and associations regularly update codes and standards, and create new ones. Since the first structural health monitoring (SHM) guide, Guidelines for SHM (ISIS Canada, 2001), was released, new SHM standards have been added around the world. These SHM codes could improve structure safety monitoring by requiring the installation of sensors on existing structures that will inform decision-makers about potential danger in time to take necessary measures and to determine if the operation period of the structure should be extended. In addition, improved standards will ensure a greater life performance of newly built bridges under different environmental loads through the implementation of proper SHM monitoring systems 
(Wiśniewski et al., 2012; Yang et al., 2017). Thus, governments and official institutions update their codes and standards regularly in response to geographic and environmental changes. Researchers have developed probability-based highway bridge studies recommending decisions based on structural reliability after disaster scenarios (Frangopol et al., 2001; Liu and Frangopol, 2004, 2006a,b). Because budgets for replacing railroads, bridges, and other structures are limited, the installation of sensors can assist in prioritizing those bridges that need to be repaired first (Moreu et al., 2014, 2015). In fact, advances in sensors and monitoring technologies make a strong argument for the fact that they should be included as part of future civil engineering structures, rather than just being added to existing infrastructure. However, to the knowledge of the authors, no American federal organization requirements for future infrastructure design and construction enforce adding sensors to future bridges and structures.

In China, a number of novel developments happened in both academic and professional areas within civil engineering. In the last several decades, the rapid growth of the Chinese economy has generated massive infrastructure development across the country. Figure 1 shows two examples of recent bridge construction sites in China. Correspondingly, civil engineering plays an important role in China (Zou et al., 2007) as the number of largescale civil infrastructures continues to increase (Yang et al., 2017). The Danyang-Kunshan Grand Bridge [166 km (102 miles)] is the longest bridge in the world, and the Langfang-Qingxian viaduct [115 km (70.8 miles)] is the second Longest Bridge (2011). The rapid emergence of new standards and codes related to civil engineering in China has also led to the development of new SHM regulations (Yang et al., 2017). More specifically, in 2016 the Chinese Ministry of Transportation published the first governmental SHM code regulating the installation of smart sensors in bridges (Ou et al., 2016). China's ability to develop and implement new civil engineering design, while rapidly increasing the size and volume of structures, can serve as a model for transportation agencies in other countries in writing, approving, and implementing their own new SHM regulations (Glaser et al., 2007). One country's new official code can serve as a reference for similar government initiatives in other countries (Xiang and Ge, 2007).

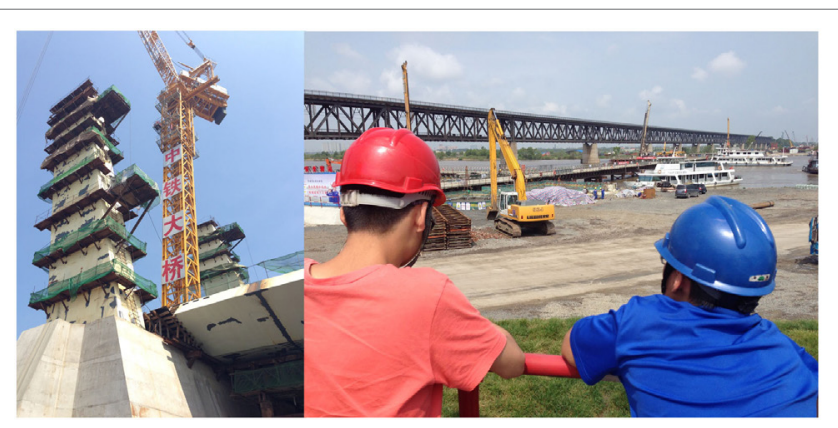

FIGURE 1 | New bridge construction in China: (left) Benxi (Liaoning province); (right) Harbin (Heilongjiang province) (courtesy by F. Moreu).
Currently, SHM only focuses on the assessment of existing infrastructure, but it can also be considered part of new structures, as well as being included in the design phase. In the United States, researchers propose to assess the condition of aging infrastructure using SHM systems (Spencer et al., 2004; Rice and Spencer, 2008). More specifically, engineers propose using data generated from monitoring an infrastructure's physical quantities (e.g., strain and temperature) to inform owners and users of their potential danger and risk. This is especially important considering that SHM systems can assess and quantify a structure's potential damage (Seth et al., 2005; Kim and Lynch, 2012). Furthermore, implementing specific steps in data postprocessing for field safety applications can inform decisionmakers about taking actions related to infrastructure condition, safety (Nagayama and Spencer, 2007; Moreu et al., 2017), and asset management (Smith, 2016). SHM technology can provide the safety evaluation of a structure when considering its serviceability, specially after disruptive damaging events when the structures need to be quickly assessed in terms of damage, assisting decisions (Ou and $\mathrm{Li}, 2010)$. SHM can also assist to quantify the long-term durability and sustainability of structures and the decay in their expected structural life, and hence they need to be designed under both considerations of the durability and sustainability of the sensors with the structure they are sensing (Loh et al., 2008). Japanese engineers and designers use control systems to increase the safety of buildings, which are combined with sensors collecting structural responses (Spencer and Nagarajaiah, 2003). Furthermore, in other scenarios, such as after earthquakes and other hazards that exert extreme loading, data obtained with sensors is useful in identifying the internal danger of the structure, which may not be detected from outside (Lynch et al., 2004). Today, there are specific building standards describing the addition of SHM systems to existing structures (Lynch, 2007). If governments could regulate and standardize SHM systems in the context of new design standards, their application (1) could help to identify existing decaying infrastructure, (2) become an integral component of design requirements, and (3) regulate the methodology needed to quantify structural damage in future possible scenarios.

Collaboration between different countries in civil engineering topics benefits researchers and engineers globally. For example, the reuse of the latest existing design code in a new discipline adapted in one country could significantly reduce the time and cost of addressing the same technical and regulatory questions in other countries. Furthermore, new codes in different countries can achieve higher quality if the editors and regulatory agencies capture and incorporate the knowledge, experience, and lessons learned by other countries (Pucher, 1995a,b; Dave and Koskela, 2009). In the last two decades, different countries have implemented successful long-term SHM systems on bridges of different types, length, and significance: the Confederation Bridge in Canada (Cheung et al., 1997); the Tsing Ma Bridge in Hong Kong (Lau et al., 2000); and the Commodore Barry Bridge in the United States (Barrish et al., 2000). In addition, real-time monitoring systems (Ko and $\mathrm{Ni}, 2005$ ) have been installed in a number of bridges in China, including the Zhanjiang Bay Bridge (Wang, 2004); the 
Xupu Bridge (Shi et al., 2000); and the Binzhou Yellow River Bridge (Ou, 2004). However, a disconnect remains between the progress of SHM systems on bridges and SHM requirements, regulations, and applications. The progress of SHM in the United States and other countries can be attributed to individual universities, states, and technical committees. There are collaborations overseas in SHM of bridges and buildings, but those are academic in nature. If legislation for SHM and sensors could be implemented worldwide, as has been accomplished in other technical engineering areas, both research development and regulations could simultaneously progress more effectively in the area of SHM.

This paper presents the new Chinese technical specification for SHM systems for highway bridges, and the relevance of this regulation to SHM and to other countries. First, this paper outlines the existing international SHM codes from different regions of the world (Canada, Europe, Australia, and USA). Additionally, the authors outline the contents of each section of the new Chinese SHM code and explain its technical relevance for the safety and management of large bridges in China. This paper also compares current SHM codes with the new SHM code from the Chinese Ministry of Transportation. Additionally, this paper introduces key Chinese-United States SHM vocabulary, as well as their definitions and semantic relevance and significance. The final consideration is a discussion of the implications for the design and implementation of a proposed new SHM code in United States and other different countries or governments, and the recommendations and considerations applicable for such similar future efforts.

\section{EXISTING SHM CODES}

Today there are SHM documents recommending SHM systems; however, those documents are not technically addressing SHM and sensor requirements, and they lack enforcement by governments as part of their new design requirement. Table 1 lists bridge maintenance and monitoring codes and standards from Australia, China, Canada, the European Union, the UK, Switzerland, and the United States. These publications are part of different regional, national, or international websites and standards from the different countries or administrations. The codes presented in this table are accessible to the wider community.

The European Union developed the structural assessment, monitoring, and control (SAMCO) association for the maintenance of infrastructure and disaster prevention (Structural Assessment, Monitoring and Control, 2006a). The SAMCO database is mainly used for infrastructure maintenance, and especially for bridge management (Structural Assessment, Monitoring and Control, 2006a). The SHM in the UK is applied to different civil infrastructures (e.g., dams, bridges, offshore installations, nuclear installations, etc.). In the UK, dams were the first structures for which legislation mandated SHM inspections, though recently more attention has focused on bridges (Brownjohn, 2007). Recommendations for SHM implementation in the UK include low-cost system (investment) and high benefit (return). The implementation of sensors, i.e., the total quantity of sensors that will be put on a structure, their positioning, the distance between them, and the algorithms and processing should be appropriately determined beforehand to avoid data overloads, including number of measurements, technical requirements, and different levels of accuracy for different sets of information collected. Environmental effects, including noise, on SHM systems could seriously influence or inhibit detection. In conclusion, the development of SHM in Europe provides good ideas and instructions for future SHM standards in other countries.

The institutions in Australia and Canada also offer promising results for SHM development. The Australian network of SHM (ANSHM) was formed in 2009 to (1) enhance development of SHM, (2) increase achievements, (3) improve national and international SHM research, and (4) raise awareness about the value of SHM in Australia (Australian Network of SHM, 2012). Articles published by ANSHM discuss the different components involved in SHM and offer suggestions regarding the future of SHM in Australia (Chan and Thambiratnam, 2014). The Canadian intelligent sensing for innovative structures, which published SHM of Innovative Canadian Civil Engineering Structures, introduced basic techniques in SHM (Mufti, 2002). It also covers topics including repairing and strengthening of structures (use of fiber-reinforced polymers), intelligent sensing (integrated fiber optic sensors, fiber bragg grating sensors), economic significance (service life of structures will be extended with SHM), remote monitoring, and intelligent processing (Mufti, 2002). Although the SHM standards from these institutions might not be enforced by their governments, the standards still give regulatory instructions for the implementation of SHM, which is supportive toward SHM code development.

\section{NEW CHINESE TECHNICAL SHM CODE}

\section{Background to Chinese SHM Documents Prior to the National SHM Code}

In recent years, Chinese provinces developed local documents and requirements which served as a preliminary standardization of regulations for the new SHM national code. In 2011, the Tianjin municipal government issued the SHM system technical specification for the bridge of Tianjin (Wang et al., 2011). This specification is focused on the condition of Tianjin's infrastructure. In 2012, the China association for engineering construction standardization published the Design standard for SHM systems (Li et al., 2012). This standard includes general directions for the design of both bridges and high-rise structures. In 2013, the ministry of housing and urban-rural development of China published the technical code for construction process analyzing and monitoring of building engineering (Mao et al., 2013). This code concentrates only on building structures. Then in 2014, the ministry of housing and urban-rural development of China issued the technical code for monitoring of building and bridge structures (Duan et al., 2014). This code included mandatory specifications regarding the SHM of high-rise structures and towers, but did not include sensor type and requirements for the SHM of highway bridges. The new Chinese technical SHM code, however, provides unprecedented nationwide instructions for the SHM of highway bridges. 
TABLE 1 | Worldwide structural health monitoring (SHM) codes/standards.

\begin{tabular}{|c|c|c|c|c|c|c|}
\hline Government & Code name (reference) & Administration & Description & Pages & Year & English \\
\hline Australia & $\begin{array}{l}\text { Structural health monitoring in Australia (Chan and } \\
\text { Thambiratnam, 2014) }\end{array}$ & Australian network of SHM & $\begin{array}{l}\text { Introduces a background of SHM, the latest } \\
\text { developments, and research conducted by } \\
\text { Australian universities }\end{array}$ & 193 & 2011 & Yes \\
\hline \multirow[t]{4}{*}{ China } & $\begin{array}{l}\text { Structural health monitoring system technical specification } \\
\text { for bridges in Tianjin (in Chinese) (Wang et al., 2011) }\end{array}$ & Tianjin municipal government & Developed for the bridge structure SHM in Tianjin & 53 & 2011 & No \\
\hline & $\begin{array}{l}\text { Design standard for structural health monitoring systems } \\
\text { (in Chinese) (Li et al., 2012) }\end{array}$ & $\begin{array}{l}\text { China association for engineering } \\
\text { construction standardization }\end{array}$ & $\begin{array}{l}\text { Used for civil engineering structure's SHM during } \\
\text { construction and service periods }\end{array}$ & 73 & 2012 & No \\
\hline & $\begin{array}{l}\text { Technical code for construction process analyzing and } \\
\text { monitoring of building engineering (in Chinese) } \\
\text { (Mao et al., 2013) }\end{array}$ & $\begin{array}{l}\text { Ministry of housing and urban-rural } \\
\text { development of China }\end{array}$ & $\begin{array}{l}\text { Designed for the construction processes that } \\
\text { analyze and monitor buildings, specifically }\end{array}$ & 65 & 2013 & No \\
\hline & $\begin{array}{l}\text { Technical code for monitoring of building and bridge } \\
\text { structures (in Chinese) (Duan et al., 2014) }\end{array}$ & $\begin{array}{l}\text { Ministry of housing and urban-rural } \\
\text { development of China }\end{array}$ & $\begin{array}{l}\text { A standard for SHM of high-rise and towering } \\
\text { structures in China }\end{array}$ & 89 & 2014 & No \\
\hline \multirow[t]{2}{*}{ Canada } & $\begin{array}{l}\text { Guidelines for structural health monitoring } \\
\text { (ISIS Canada, 2001) }\end{array}$ & $\begin{array}{l}\text { Intelligent sensing for innovative } \\
\text { structures (ISIS) }\end{array}$ & $\begin{array}{l}\text { Illustrates the benefits of SHM for engineers who } \\
\text { are new to this area }\end{array}$ & 127 & 2001 & Yes \\
\hline & $\begin{array}{l}\text { Reinforcing concrete structures with fiber-reinforced } \\
\text { polymers (FRPs) (Reinforcing Concrete Structures with } \\
\text { Fiber Reinforced Polymers, 2007) }\end{array}$ & ISIS & $\begin{array}{l}\text { Provides design guidelines for FRP-reinforced } \\
\text { concrete structures }\end{array}$ & 151 & 2007 & Yes \\
\hline \multirow[t]{9}{*}{ European Union } & $\begin{array}{l}\text { Strategic research agenda (Structural Assessment, } \\
\text { Monitoring and Control, 2006b) }\end{array}$ & $\begin{array}{l}\text { Europe structural assessment, } \\
\text { monitoring, and control (SAMCO) }\end{array}$ & An introduction to SAMCO's research agenda & 35 & 2006 & Yes \\
\hline & $\begin{array}{l}\text { SAMCO monitoring glossary (Structural Assessment, } \\
\text { Monitoring and Control, 2006b) }\end{array}$ & SAMCO & $\begin{array}{l}\text { Structural dynamics for vibration-based health } \\
\text { monitoring of bridges }\end{array}$ & 198 & 2006 & Yes \\
\hline & $\begin{array}{l}\text { Ambient vibration monitoring (Structural Assessment, } \\
\text { Monitoring and Control, 2006b) }\end{array}$ & SAMCO & Introduction to the ambient vibration method & 243 & 2006 & Yes \\
\hline & $\begin{array}{l}\text { Case studies (Structural Assessment, Monitoring and Control, } \\
\text { 2006b) }\end{array}$ & SAMCO & Summary of SAMCO projects & 170 & 2006 & Yes \\
\hline & $\begin{array}{l}\text { Guidelines for structural control (Structural Assessment, } \\
\text { Monitoring and Control, 2006b) }\end{array}$ & SAMCO & $\begin{array}{l}\text { Overview of damping devices and control } \\
\text { algorithms }\end{array}$ & 155 & 2006 & Yes \\
\hline & $\begin{array}{l}\text { SAMCO history and events (Structural Assessment, } \\
\text { Monitoring and Control, 2006b) }\end{array}$ & SAMCO & Introduction to the history of SAMCO & 56 & 2006 & Yes \\
\hline & $\begin{array}{l}\text { Guideline for the assessment of existing structures } \\
\text { (Structural Assessment, Monitoring and Control, 2006b) }\end{array}$ & SAMCO & Principles and routines for structural assessment & 48 & 2006 & Yes \\
\hline & $\begin{array}{l}\text { Guideline for structural health monitoring } \\
\text { (Structural Assessment, Monitoring and Control, 2006b) }\end{array}$ & SAMCO & $\begin{array}{l}\text { Introduction to existing procedures and } \\
\text { technologies and recommendations for SHM } \\
\text { application }\end{array}$ & 63 & 2006 & Yes \\
\hline & $\begin{array}{l}\text { Report on bridge management (Structural Assessment, } \\
\text { Monitoring and Control, 2006b) }\end{array}$ & SAMCO & $\begin{array}{l}\text { Introduction to bridge management and end-user } \\
\text { requirements }\end{array}$ & 184 & 2006 & Yes \\
\hline UK & $\begin{array}{l}\text { Structural health monitoring of civil infrastructure } \\
\text { (Brownjohn, 2007) }\end{array}$ & $\begin{array}{l}\text { Philosophical transactions of the royal } \\
\text { society of London }\end{array}$ & History and state-of-the-art developments of SHM & 34 & 2006 & Yes \\
\hline
\end{tabular}
society of London 
TABLE 2 | New Chinese structural health monitoring (SHM) code content.

\begin{tabular}{ll}
\hline Chapter & Contents \\
\hline 1 & General scope \\
2 & Normative references and documents \\
3 & Terminology and definitions \\
4 & Overall design and requirements \\
5 & Monitored parameters and locations selection \\
6 & Sensors \\
7 & Data acquisition, transmission, processing, and management \\
8 & Structural safety evaluation and alarm \\
9 & Integrated SHM systems and status display
\end{tabular}

\section{Need of a National Technical SHM Code in China}

Structural health monitoring systems in China began to be used in the early 2000s (Li et al., 2006). Since 2004, new SHM technologies have been implemented on long-span bridges (Li et al., 2015; $\mathrm{Li}$ and $\mathrm{Ou}, 2016)$. During all these years of SHM growth in China, many problems emerged from the application of SHM on their bridges. Users of SHM systems could not identify the specific life-span required for sensors installed on bridges and were not familiar with maintenance procedures once installed. Moreover, researchers were not able to communicate in a formal document a general requirement about the number of sensors and cost of SHM systems for bridges. Finally, the large amounts of data received from SHM systems were not systematically analyzed and deeply mined, and the information was not able to inform decision making on bridge maintenance. Therefore, the existing SHM system documents and standards did not provide directions or regulations that could be standardized and enforced.

To resolve this problem, and with grants from the National Natural Science Foundation of China, the Ministry of Science and Technology, and the Chinese industry (Bao et al., 2013), extensive research was carried out which provided a solid foundation for the systematic description of the specific SHM needs for bridges in China. As a result, it was necessary to make the design and implementation of highway bridge SHM a formal procedure for Chinese highway bridge preservation, sustainability, and durability; and a comprehensive SHM standard that would be available to both governments and construction companies. The problems mentioned above could be solved if comprehensive studies, engineering experience, and research results could be incorporated. Researchers and engineers in the SHM field and leaders in bridge engineering in China thus wrote the technical specification for SHM systems of highway bridges for the Chinese Ministry of Transportation.

\section{TECHNICAL CONTENTS OF THE NEW CHINESE SHM CODE}

The technical contents of the new Chinese SHM code are summarized in Table 2. The following sections include a discussion of the key technical topics related to its implementation, such as sensors, data, and safety evaluation. The authors have extracted the most important information and practical SHM engineering 
TABLE 3 | New Chinese structural health monitoring code sensor requirements.

\begin{tabular}{|c|c|c|c|}
\hline \multirow[t]{2}{*}{ Sensor type } & \multicolumn{2}{|r|}{ Requirements } & \multirow[t]{2}{*}{ Section } \\
\hline & Specific areas & Accuracy, range, resolution, sensitivity, resolution & \\
\hline \multirow{6}{*}{$\begin{array}{l}\text { Load and environment } \\
\text { monitoring senor }\end{array}$} & Vehicle load monitoring & Range $\geq 200 \%$ of the axle load & 6.2 .1 \\
\hline & $\begin{array}{l}\text { Wind speed and wind direction } \\
\text { monitoring }\end{array}$ & Range $\geq$ design wind speed of its installation height & 6.2 .2 \\
\hline & Wind pressure monitoring & $\begin{array}{l}-1,000 \mathrm{~Pa}(-0.145 \mathrm{Psi})<\text { range < 1,000 Pa (0.145 Psi); } \\
-2 \mathrm{~Pa}(-0.00029 \mathrm{Psi})<\text { measurement error < } 2 \mathrm{~Pa}(0.00029 \mathrm{Psi})\end{array}$ & 6.2 .3 \\
\hline & Temperature monitoring & $\begin{array}{l}\text { Atmospheric temperature: } \\
\text { Year extreme minimum temperature }-20^{\circ} \mathrm{C}\left(-4^{\circ} \mathrm{F}\right) \leq \text { range } \leq \text { year maximum } \\
\text { temperature }+20^{\circ} \mathrm{C}\left(+68^{\circ} \mathrm{F}\right) \text {; } \\
\text { Accuracy } \geq \pm 0.5^{\circ} \mathrm{C}\left(31.1 \sim 32.9^{\circ} \mathrm{F}\right) \text {; resolution } \geq \pm 0.1^{\circ} \mathrm{C}\left(31.82 \sim 32.18^{\circ} \mathrm{F}\right)\end{array}$ & 6.2 .6 \\
\hline & & $\begin{array}{l}\text { Structural surface temperature: } \\
\text { Year extreme minimum temperature }-20^{\circ} \mathrm{C}\left(-4^{\circ} \mathrm{F}\right) \leq \text { range } \leq \text { year maximum } \\
\text { temperature }+20^{\circ} \mathrm{C}\left(+68^{\circ} \mathrm{F}\right) \text {; } \\
\text { Accuracy } \geq \pm 0.2^{\circ} \mathrm{C}\left(31.64 \sim 32.36^{\circ} \mathrm{F}\right) \text {; resolution } \geq \pm 0.1^{\circ} \mathrm{C}\left(31.82 \sim 32.18^{\circ} \mathrm{F}\right)\end{array}$ & \\
\hline & Humidity monitoring & Range: 0-100\% RH; accuracy $\geq 3 \% \mathrm{RH}$ & 6.2 .7 \\
\hline \multirow[t]{2}{*}{$\begin{array}{l}\text { Structural global response } \\
\text { monitoring sensor }\end{array}$} & Accelerometer & $\begin{array}{l}\text { Large span bridge with low-natural frequency: } \\
\text { Frequency response range: } 0 \sim 100 \mathrm{~Hz} \\
\text { Range } \geq \pm 2 \text { g; transverse sensitivity }<1 \%\end{array}$ & 6.3 .1 \\
\hline & & $\begin{array}{l}\text { Bridge structure with high-natural frequency: } \\
\text { Frequency response range: } 0.2 \sim 1,000 \mathrm{~Hz} \\
\text { Range } \geq \pm 20 \mathrm{~g} \text {; transverse sensitivity }<5 \%\end{array}$ & \\
\hline $\begin{array}{l}\text { Structural local response } \\
\text { monitoring sensor }\end{array}$ & Strain sensor & $\begin{array}{l}30 \% \text { full range }<\text { static strain measurement }<80 \% \text { full range } \\
\text { Range of dynamic strain gage } \geq 2 \times \text { maximum predicted value }\end{array}$ & 6.4 .1 \\
\hline
\end{tabular}

technical parameters to show that the code can be useful to other institutions wanting to develop their own SHM codes. More importantly, the technical parameters included in the following tables are can be used to purchase SHM equipment according to different cases. Since this represents the first official highway bridge SHM code, the authors have mostly organized the contents and describe formally the parameters so the new code can be understood by readers with a general background and not necessarily expertise in SHM of highway bridges. The authors believe that the presentation of tables and figures assist for a general access of the community to the relevance of the new Chinese SHM Code.

\section{SHM APPLICABILITY}

According to the new Chinese SHM Code, the bridge that needs to have sensors installed are: beam style reinforced concrete bridges with more than $150 \mathrm{~m}$ span; arch bridges with more than $200 \mathrm{~m}$ span; cable-suspended bridges with more than $300 \mathrm{~m}$ span; suspended bridges with more than $500 \mathrm{~m}$ span; and other complex and important bridges. Other bridges' SHM system could also use this code as a reference or guide to specify their own SHM requirements depending on the type of structures they are worried for their own territory. As for the general requirements for SHM system and sensors, the new SHM Chinese code specifies that the embedded monitoring equipment's durability should be at least 20 years and the non-embedded monitoring equipment's durability should be at least 5 years. Finally, the new Chinese SHM code points out that when related to conditions of maintenance and replaceability, new bridge SHM systems should have the same durability as the bridges these systems are monitoring.

\section{SENSORS REQUIREMENTS}

The summary of the sensor section of the new Chinese SHM code is shown in Table 3 and it is introduced from the perspective of parameter requirements for different sensors. The sensor type and requirements are listed for different applications: load and environment monitoring, structural global response monitoring, and structural local response monitoring. Corresponding to different application areas, there are different requirements for the technical parameters of sensors.

\section{DATA REQUIREMENTS}

Table 4 introduces the summary of the different types of data from the perspective of technical parameters corresponding to different applications. The data section is divided into four parts: collection, transmission, processing, and management.

\section{SAFETY EVALUATION REQUIREMENTS}

The new Chinese code includes different requirements for safety evaluation, which are outlined in Table 5. It also introduces firstlevel and second-level safety evaluation. Their relationships and definitions are illustrated in Figure 2 and Table 6. According to the results of the first data analysis, first-level safety evaluation should be implemented. If the structural global response is found 
TABLE 4 | New Chinese structural health monitoring code data requirements.

\begin{tabular}{|c|c|c|c|}
\hline \multirow{2}{*}{ Data } & \multirow[b]{2}{*}{ Equipment selection } & Requirements & \multirow{2}{*}{ Section } \\
\hline & & $\begin{array}{l}\text { Charge signal: charge amplifier } \\
\text { Digital signal: RS485, CAN, Modbus TCP, or UDP distributed data collection } \\
\text { Analog signal: } 4-20 \mathrm{~mA} \text { and }+5 \mathrm{~V}\end{array}$ & \\
\hline & Sampling frequency & $\begin{array}{l}\text { Load and environment monitoring: minimum value } \\
\text { Boat piers acceleration: } 50 \mathrm{~Hz} \text {; wind pressure: } 20 \mathrm{~Hz} \text {; earthquake: } 50 \mathrm{~Hz} \text {; temperature: 1/600 Hz; } \\
\text { humidity: } 1 / 600 \mathrm{~Hz} \text {; rainfall: } 1 / 60 \mathrm{~Hz}\end{array}$ & 7.2 .4 \\
\hline & & $\begin{array}{l}\text { Structural global and local response monitoring: minimum value } \\
\text { Vibration acceleration: } 50 \mathrm{~Hz} \text {; moving displacement: } 20 \mathrm{~Hz} \\
\text { Static displacement: } 1 \mathrm{~Hz} \text {; dynamic strain: } 20 \mathrm{~Hz} \text {; static strain: } 1 / 3,600 \mathrm{~Hz} \\
\text { Support reaction: } 1 \mathrm{~Hz}\end{array}$ & \\
\hline & $\begin{array}{l}\text { Time synchronization } \\
\text { accuracy }\end{array}$ & $\begin{array}{l}\text { Same type of monitoring variables: }<0.1 \mathrm{~ms} \\
\text { Different same type of monitoring variables: }<1 \mathrm{~ms}\end{array}$ & 7.2 .5 \\
\hline Data transmission & Transmission distance & $\begin{array}{l}\text { Relatively short and without strong electromagnetic interference: analog signal } \\
\text { Far or strong electromagnetic interference: digital signal } \\
\text { Up to a few kilometers or even tens of kilometers: optical fiber transmission }\end{array}$ & 7.3 .2 \\
\hline Data processing & $\begin{array}{l}\text { Preprocessing } \\
\text { Postprocessing }\end{array}$ & $\begin{array}{l}\text { Digital filtering, denoising, intercepting, and exception handling } \\
\text { Specialized design }\end{array}$ & 7.4 .1 \\
\hline Data management & Functions: quick displa & cient storage, report generation, and data archiving & 7.5 .1 \\
\hline
\end{tabular}

TABLE 5 | New Chinese structural health monitoring code safety evaluation requirements.

\begin{tabular}{|c|c|c|c|}
\hline \multirow{2}{*}{$\begin{array}{l}\text { Safety } \\
\text { Safety } \\
\text { warning }\end{array}$} & \multicolumn{2}{|c|}{$\begin{array}{ll}\text { Requirements }\end{array}$} & \multirow{2}{*}{$\begin{array}{c}\text { Section } \\
8.2 .2\end{array}$} \\
\hline & $\begin{array}{l}\text { Yellow and red } \\
\text { warning }\end{array}$ & $\begin{array}{l}\text { Total weight of the vehicle or axle weight }>\text { design vehicle load } \times 1.5 \rightarrow \text { yellow } \\
(>\text { design vehicle load } \times 2.0 \rightarrow \text { red) } \\
\text { Maximum average wind speed }>\text { design wind speed } \times 0.8 \rightarrow \text { yellow } \\
\text { (>design wind speed } \rightarrow \text { yellow) } \\
\text { Maximum/minimum temperature, maximum temperature difference, and maximum temperature } \\
\text { gradient }>\text { design value } \rightarrow \text { yellow } \\
\text { Displacement }>\text { design value } \times 0.8 \rightarrow \text { yellow } \\
(>\text { design value or more than } 10 \text { yellow warnings appear within a month } \rightarrow \text { red) }\end{array}$ & \\
\hline \multirow[t]{3}{*}{ Data analysis } & $\begin{array}{l}\text { Load and } \\
\text { environment }\end{array}$ & $\begin{array}{l}\text { (a) Vehicle load parameters: bridge traffic, vehicle type, axle weight, gross weight, speed, and } \\
\text { overload ratio } \\
\text { (b) Wind parameters: speed, direction } \\
\text { (c) Earthquake data: acceleration peak, velocity peak, duration, spectrum, and response spectrum } \\
\text { (d) Temperature data: maximum/minimum temperature, the maximum temperature gradient of the section } \\
\text { (e) Humidity data: maximum internal/external humidity of the component, mean value, and time exceeding } \\
\text { the limit } \\
\text { (f) Rainfall data: maximum rainfall per hour, cumulative rainfall }\end{array}$ & 8.3 .2 \\
\hline & $\begin{array}{l}\text { Structural global } \\
\text { response monitoring }\end{array}$ & $\begin{array}{l}\text { (a) Acceleration: absolute maximum, maximum root mean square value } \\
\text { (b) Deformation: mean, absolute maximum } \\
\text { (c) Displacement: maximum, cumulative displacement } \\
\text { (d) Modal parameters: frequency, mode, and damping ratio }\end{array}$ & 8.3 .3 \\
\hline & $\begin{array}{l}\text { Structural local } \\
\text { response monitoring }\end{array}$ & $\begin{array}{l}\text { Strain: mean, maximum, minimum, stress amplitude maximum; } \\
\text { support reaction time course: mean, maximum/minimum, and maximum change }\end{array}$ & 8.3 .4 \\
\hline $\begin{array}{l}\text { Special } \\
\text { assessment }\end{array}$ & \multicolumn{2}{|c|}{$\begin{array}{l}\text { (a) Maximum average wind speed > design wind speed } \\
\text { (b) earthquake horizontal acceleration peak > design E1 earthquake's corresponding acceleration peak } \\
\text { (c) the bridge was hit by a boat } \\
\text { (d) the bridge is flooded }\end{array}$} & 8.3.1-8.3.4 \\
\hline
\end{tabular}

abnormal, second-level safety evaluation should be conducted. If the structural local response is found abnormal, special assessment should be performed. If bridge damage is found during the special assessment, the second-level safety evaluation should be implemented based on the monitored data and special assessment results.

\section{KEY CHINESE-UNITED STATES SHM VOCABULARY}

Table 6 introduces the key Chinese-United States SHM vocabulary and their definitions. The vocabulary outlined in the Chinese SHM code also applies to other SHM codes in other countries 


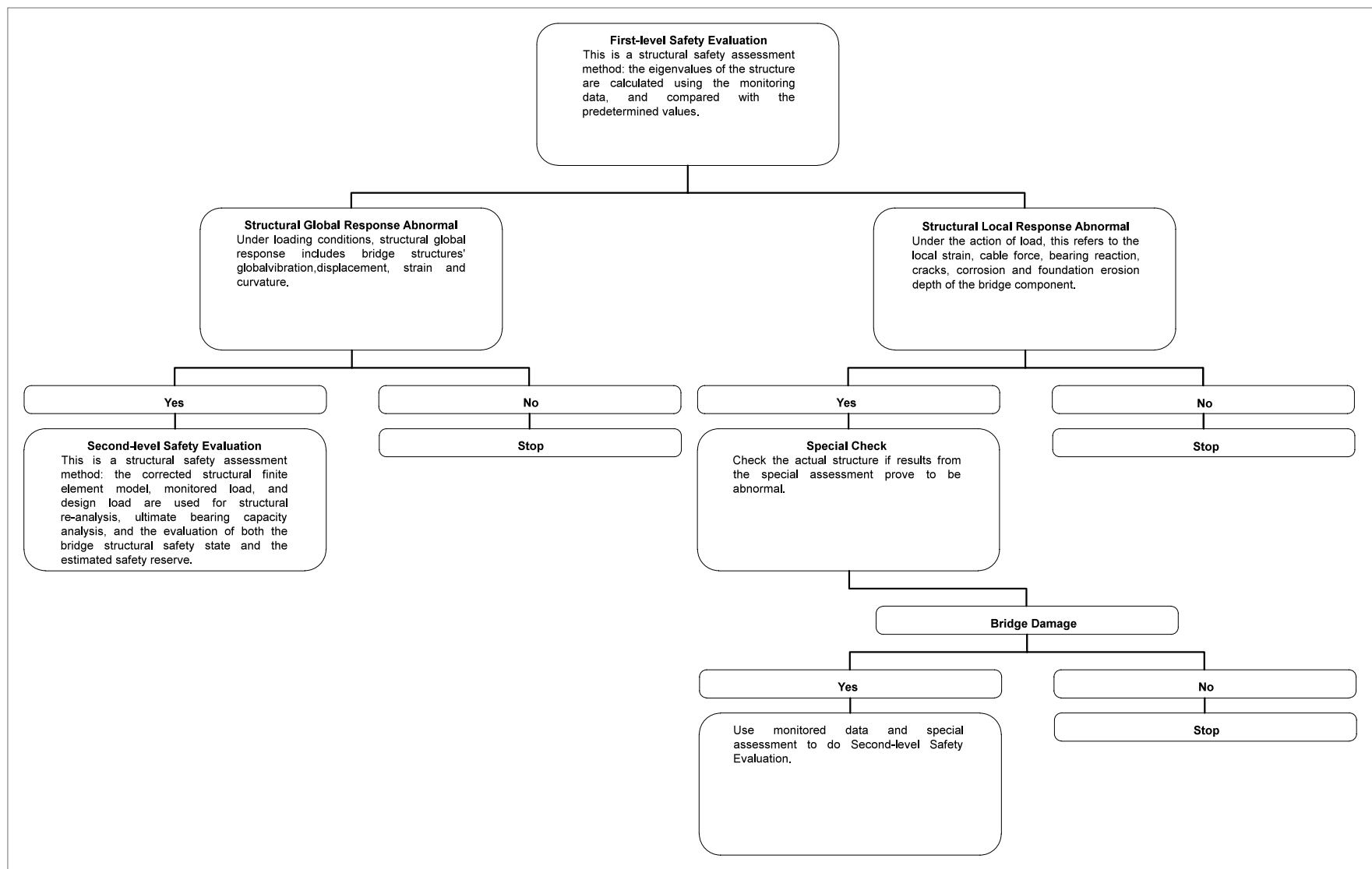

FIGURE 2 | First-level safety evaluation decision tree.

since most of them are general concepts. Collaboration in SHM among different countries is important, and therefore translation of terminologies must be accurate. Semantic understanding of these terms is key in applying this code in different countries.

\section{COMPARISON BETWEEN EXISTING SHM CODES AND THE NEW CHINESE SHM CODE}

In order to better understand the relevance of the new Chinese SHM code in comparison with the current SHM codes listed in Table 1, the authors have made comparisons in four different aspects: information and content, and scope; legislation and enforcement; technical contents and procedures; and sensor details and requirements/descriptions. The authors believe that this general comparison can serve the international SHM community to identify similarities, differences, and relevance of the different codes, as well as to better understand the contributions of the new Chinese SHM code in the context of the existing published efforts.

Related to information and contents from the existing codes listed in Table 1, the majority of the existing SHM standards focus on the area of historical and description of the current/existing SHM technology, with an emphasis on past and current experiences. In a similar note, the existing codes in general introduce the general idea of SHM applications, but do not specifically focus on the preservation of highway bridges. Canada's standard is the earliest among all the standards chronologically. In many cases, most of the published codes have been edited and produced through institutions, such as SAMCO of Europe. In general, most of the existing SHM codes to date are in English. Other related SHM codes or regulations such as the SHM standards from Germany (Österreichische Forschungsgellschaft, 2012) and Russia (Interstandard, 2010), are not listed in Table 1 since the specific contents are not currently accessible to the broad community. The new Chinese SHM code is approved by the Chinese Ministry of Transportation, which in some level is more authoritative, when compared with other codes already developed within China. Finally, the new Chinese SHM code is specifically directed toward applications for highway bridges.

From the perspective of legislation, most organizations who published those codes have limited power to make those codes required or enforced in design, construction, or management, so they become a recommendation or proposed path, as opposed as a code. For example, SAMCO (from Europe) provides a very detailed description about SHM technology, but it is provided within the context of an introduction of procedures, giving recommendations for their application (Guideline for SHM, 2017). Similarly, the code developed by the federal highway administration (FHWA) (U.S. Department of Transportation, 2012) was only intended to introduce the concept of SHM to bridge owners 
TABLE 6 | Structural health monitoring (SHM) Chinese-United States vocabulary.

\begin{tabular}{|c|c|c|c|}
\hline No. & Chinese name & Name & Definition \\
\hline 1 & 结构安全监测系统 & $\begin{array}{l}\text { Structural safety monitoring } \\
\text { system }\end{array}$ & $\begin{array}{l}\text { It is a system constituted of software and hardware and includes sensors, data collection } \\
\text { and transmission, data processing and management, etc. The system has the function of } \\
\text { measuring, collecting, processing, and analyzing bridge performance parameters. It can also } \\
\text { evaluate and offer early-warnings for bridge safety status }\end{array}$ \\
\hline 2 & 传感器耐久性 & Durability of sensor & $\begin{array}{l}\text { The ability of a sensor to maintain normal working condition and resist the effects of } \\
\text { environment }\end{array}$ \\
\hline 3 & 环境参数 & Environmental parameter & $\begin{array}{l}\text { The natural environment parameters of the area where the bridge is located, such as wind, } \\
\text { temperature, humidity, rainfall, etc. }\end{array}$ \\
\hline 4 & 结构整体响应 & Structural global response & $\begin{array}{l}\text { Under loading conditions, structural global response includes bridge structures' global } \\
\text { vibration, displacement, strain, and curvature }\end{array}$ \\
\hline 5 & 结构局部响应 & Structural local response & $\begin{array}{l}\text { Under the action of load, this refers to the local strain, cable force, bearing reaction, cracks, } \\
\text { corrosion, and foundation erosion depth of the bridge component }\end{array}$ \\
\hline 6 & 结构失效 & Structural failure & A bridge structure system or key component loses from its original design function \\
\hline 7 & 结构退化 & Structural deterioration & Structural capacity gets weaker due to the natural environment and load over time \\
\hline 8 & 结构状态估计 & Structural state estimation & $\begin{array}{l}\text { According to the environment, load, structure response, and structural performance } \\
\text { parameters obtained by the monitoring system, estimation of the structural internal force state, } \\
\text { plotting diagrams, such as shear/moment/torsion, estimated by using structural engineering } \\
\text { methods updated with data }\end{array}$ \\
\hline 9 & 模态参数 & Modal parameter & $\begin{array}{l}\text { The inherent structural dynamic properties of the structure, including natural frequencies, } \\
\text { damping ratios, and modal vibration modes }\end{array}$ \\
\hline 10 & 模态参数识别 & Modal parameter identification & $\begin{array}{l}\text { Implementation of the modal recognition technique on the monitored bridge structure } \\
\text { response and external excitation data, obtaining the modal parameters of the bridge }\end{array}$ \\
\hline 11 & 安全评估 & Safety evaluation & $\begin{array}{l}\text { Analysis of the bridge's current working status using monitoring data, by comparing the } \\
\text { resultant working status with corresponding critical failure state to evaluate bridge's safety level }\end{array}$ \\
\hline 12 & 安全一级评估 & Safety evaluation (first level) & $\begin{array}{l}\text { This is a structural safety assessment method: the eigenvalues of the structure are calculated } \\
\text { using the monitoring data, and compared with the predetermined values }\end{array}$ \\
\hline 13 & 安全二级评估 & Safety evaluation (second level) & $\begin{array}{l}\text { This is a structural safety assessment method: the corrected structural finite element model, } \\
\text { monitored load, and design load are used for structural re-analysis, ultimate bearing capacity } \\
\text { analysis, and the evaluation of both the bridge structural safety state and the estimated safety } \\
\text { reserve }\end{array}$ \\
\hline 14 & 预警值 & Alarming value & $\begin{array}{l}\text { This is a warning value of the monitoring parameter from the equipment located at } \\
\text { corresponding monitoring positions. This warning value is set according to different levels of } \\
\text { danger to the bridge operating environment and structural components }\end{array}$ \\
\hline 15 & 预警 & Early-warning & $\begin{array}{l}\text { This is an action: the safety monitoring system reports an abnormal situation to relevant } \\
\text { departments when the monitoring data eigenvalue exceeds the alarming value or threshold }\end{array}$ \\
\hline 16 & 专项评估 & Special assessment & $\begin{array}{l}\text { When an accident occurs (e.g., floods or a ship striking), the SHM system makes an } \\
\text { assessments based on the actual occurrence. Compare assessment results with the } \\
\text { predetermined standards or thresholds }\end{array}$ \\
\hline 17 & 专项检查 & Special check & Check the actual structure if results from the special assessment prove to be abnormal \\
\hline
\end{tabular}

so that they could make better informed decisions (Aktan et al., 2002). Neither of these former publications has the same legislative relevance as the new Chinese SHM code, approved by the Chinese Ministry of Transportation.

From the perspective of technical contents and procedures, many of the SHM standards listed in Table 1 introduce the state-ofthe-art of advanced sensors, and their successful implementations on structures in the past by case studies or bridge applications. For example, the code from UK introduces fiber optic sensors, GPS, and piezo-impedance transducers as well as their successful applications in the past (Brownjohn, 2007). Similarly, the code from SAMCO outlines the most popular sensors and their parameters (Guideline for SHM, 2017). However, SAMCO summarizes the sensors in a table rather than categorizing the different monitoring purposes, requirements, etc. The existing SHM code descriptions reviewed to the best knowledge of the authors of this paper do not formally outline procedures or instructions that can be followed and applied by bridge construction companies and/ or bridge owner. The new Chinese SHM code determines which sensors are needed to monitor (for example: strain, acceleration, temperature, humidity); what sensor parameters are required and how to measure them; what decisions to take based on those measurements; and how to collect data and use it for different decisions for different monitoring purposes (such as structural global response or environment monitoring). In conclusion, the new Chinese SHM code provides specific procedures that can be followed by designers, construction companies, and bridge owners. 
As it relates to sensor technical requirements, including sensor durability, most codes only mention this broadly. For example, the code from the FHWA (U.S. Department of Transportation, 2012) mentions the concept of sensor durability in the bridge health's performance section (Aktan et al., 2002). The new Chinese SHM code outlines the requirements of the durability of sensor, at least 20 years for the embedded sensors' durability at least 5 years for the non-embedded sensors. This unique level of details sets a precedent in the SHM regulatory scene, giving owners an exact time period requirement for the sensors they choose, enhancing the safety of the SHM systems, and the safety of highway bridges by addressing the sustainability of the sensors and systems required in the code.

In conclusion, the new Chinese SHM code is more specific than its predecessors in the scope, its legislative relevance, the enforcement of technical parameters for decision making by owners, and the level of detail in the sensor requirements, such as their durability over time.

\section{NEW SHM CODE CONSIDERATIONS IN THE UNITED STATES AND OTHER COUNTRIES}

Future development of new SHM code in the United States and other countries could benefit using elements from the new Chinese SHM code. It would be valuable for institutions or governments to review the Chinese SHM code and use it as a first reference on SHM governmental regulation when no other experience or documents are available. The evaluation process of the new SHM code from the Chinese Ministry of Transportation could benefit the United States and other governments after the new code is implemented in China. It will be necessary to consider the differences between the countries where a new SHM code would be written. Such differences include, but are not limited to: geography, population, socio-economic factors, and administrations. For example, the United States is administrated by local, state, and federal governments. On the other hand, in China, the two main systems that develop standards and codes for construction engineering are the government of China and the professional associations regulating those engineering works (Yang et al., 2017). In addition, the technical differences must also be considered for future SHM codes that may be available in the near future. Cost-effective sensors available today are technologically more capable and financially more affordable than they were 5 years ago (Gomez et al., 2016, 2017). As a result, the future SHM code designed for United States and other countries could incorporate more advanced sensors and equipment which can be affordable by administrations of all sizes. In addition, there are currently more advanced data analysis methods that are emerging related to new areas of knowledge that can transform SHM, such as machine learning and artificial intelligence. Other new SHM parameters that should be included in future SHM codes related to real-time performance and assessment include measuring displacement using reference-free methods (Ozdagli et al., 2017), control systems (Garg et al., 2017), and bridge dynamics (Vemuganti et al., 2017). Finally, international collaboration between different institutions, specially with Chinese institutions, is much more possible today than in the past. Future discussions and considerations about a new United States SHM code could benefit from international collaborations, and has the potential to generate greater advancements in the United States SHM code, and for other future new SHM codes around the world.

\section{CONCLUSION}

This paper introduces a new SHM code designed and proposed in China by the Chinese Ministry of Transportation. This paper outlines the contents of the new Chinese SHM code, and the requirement of sensors becoming part of federal requirements for future bridge design and construction. The authors explain the relevance of the code for the safety and management of large bridges in China, and introduces key definitions of the ChineseUnited States SHM vocabulary and their technical significance. A comparison with current SHM publications across the world is also outlined. A future new SHM code for the United States and other countries can also be proposed based on similarities and differences with the Chinese code. The future SHM codes can incorporate the lessons learned by the Chinese Ministry of Transportation in developing and publishing legislation for SHM, also result in safer and more specifically outlined bridge SHM operations, methodologies, and implementations toward formal integration of technology by bridge owners. The considerations mentioned in this paper are also applicable for future similar efforts in different countries and within other governments. The conclusions of this paper are only those of the authors.

\section{AUTHOR CONTRIBUTIONS}

FM directed the general organization of the research and study to prepare this paper, in particular the organization, comparison, and translation of the different SHM codes, with an emphasis on the SHM Chinese code. FM visited CCCC, HIT, and various bridge construction sites and synthesized the contents of the Chinese SHM in the context of other SHM codes. XL conducted the international comparison of SHM codes as well as the graphs and tables presented in the paper. SL assisted FM in coordinating interviews with different bridge officials, visiting bridge construction sites, and provided with a general description of the Chinese SHM code. DZ provided with a general review of the contents and motivations for the creation of the SHM code by the Chinese ministry of transportation. FM, SL, and DZ met with CCCC headquarters in Beijing in 2014 for the final review and approval of the new SHM Chinese code.

\section{ACKNOWLEDGMENTS}

The authors of this paper thank the following engineers for their input in accessing the new Chinese SHM code: Professor Hui Li (HIT), Professor Jinping Ou (HIT), bridge engineer Na Li (China Communications Construction Company, Ltd.), and Professor Bill F. Spencer (University of Illinois at Urbana-Champaign). The authors are grateful to Dr. Carman Melendrez and Mr. Hossein Goudarzi from the University of New Mexico (Vice President 
Research Office): their suggestions and comments helped enhance the quality and content of the final version of this manuscript. The financial support from the US Foreign Language and Area Studies (FLAS) Fellowships program at the US Department of Education (2017), the Center for Global Studies at the University of Illinois at Urbana-Champaign, and the Center for East Asian and Pacific

\section{REFERENCES}

Aktan, A. E., Catbas, F. N., Grimmelsman, K. A., and Pervizpour, M. (2002). Development of a model health monitoring guide for major bridges. Rep. Dev. FHWA Res. Dev. Available at: https://www.scribd.com/document/343127708/ Development-of-a-Model-Health-Monitoring-Guide-for-Major-Bridges

Australian Network of SHM. (2012). Available at: http://www.anSHM.org.au/ introduction.html

Bao, Y., Li, H., Sun, X., Yu, Y., and Ou, J. (2013). Compressive sampling-based data loss recovery for wireless sensor networks used in civil structural health monitoring. SHM 12, 78-95. doi:10.1177/1475921712462936

Barrish, R. A. Jr., Grimmelsman, K. A., and Aktan, A. E. (2000). "Instrumented monitoring of the Commodore Barry bridge," in SPIE's 5th Annual International Symposium on Nondestructive Evaluation and Health Monitoring of Aging Infrastructure (Newport Beach, CA: International Society for Optics and Photonics), 112-126.

Brownjohn, J. M. (2007). Structural health monitoring of civil infrastructure. Philos. Trans. R. Soc. London A 365, 589-622. doi:10.1098/rsta.2006.1925

Brühwiler, E., Faber-Nielsen, M. H., Isler, A., Lang, T. P., Lüchinger, P., Putallaz, J., et al. (2011). Fundamentals of the Conservation of Structures. Zurich: SIA. SIA 269.

Chan, T., and Thambiratnam, D. P. (2014). SHM in Australia. New York: Nova Science.

Cheung, M. S., Tadros, G. S., Brown, T., Dilger, W. H., Ghali, A., and Lau, D. T. (1997). Field monitoring and research on performance of the Confederation Bridge. Can. J. Civil Eng. 24, 951-962. doi:10.1139/197-081

Dave, B., and Koskela, L. (2009). Collaborative knowledge management-a construction case study. Automat. Construct. 18, 894-902. doi:10.1016/ j.autcon.2009.03.015

Duan, X. S., Chang, L., Guo, Z. W., Yang, Y., Wang, N., Di, X. T., et al. (2014). Jian zhu yu qiao liang jie gou jian ce ji shu gui fan [Technical Code for Monitoring of Building and Bridge Structures]. Zhong hua ren min gong he guo zhu fang he cheng xiang jian she bu, GB 50982-2014 (in Chinese).

Frangopol, D. M., Kong, J. S., and Gharaibeh, E. S. (2001). Reliability-based life-cycle management of highway bridges. J. Comput. Civil Eng. 15, 27-34. doi:10.1061/(ASCE)0887-3801(2001)15:1(27)

Garg, P., Ozdagli, A., and Moreu, F. (2017). "Optimal bridge displacement controlled by train speed on real-time," in Dynamics of Civil Structures. Conference Proceedings of the Society for Experimental Mechanics Series, eds J. Caicedo and S. Pakzad, Vol 2 (Cham: Springer), 291-299.

Glaser, S. D., Li, H., Wang, M. L., Ou, J., and Lynch, J. (2007). Sensor technology innovation for the advancement of structural health monitoring: a strategic program of US-China research for the next decade. Smart Struct. Syst. 3, 221-244. doi:10.12989/sss.2007.3.2.221

Gomez, J. A., Ozdagli, A. I., and Moreu, F. (2016). "Application of low-cost sensors for estimation of reference-free displacements under dynamic loading for railroad bridges safety," in ASME. Smart Materials, Adaptive Structures and Intelligent Systems, Volume 1: Multifunctional Materials; Mechanics and Behavior of Active Materials; Integrated System Design and Implementation; Structural Health Monitoring. V001T05A021, 11. doi:10.1115/SMASIS2016-9294

Gomez, J. A., Ozdagli, A. I., and Moreu, F. (2017). Reference-free dynamic displacements of railroad bridges using low-cost sensors. J. Intell. Mater. Syst. Struct. 1-15. doi:10.1177/1045389X17721375

Hooks, J. M., and Weidner, J. (2016). Long-Term Bridge Performance Program Protocols, Version 1 (No. FHWA-HRT-16-007). McLean, VA: Research, Development, and Technology Turner-Fairbank Highway Research Center.

Interstandard. (2010). Building and Structures, Technical Inspections and Monitoring Regulations, GOST R 53778:2010. Moscow: Russian scientific and technical center for information on standardization, metrology and conformity assessment.
Studies at the University of Illinois at Urbana-Champaign is also acknowledged. The financial support from the New Mexico Consortium under grant number 249-01, and the Transportation Consortium on South-central States (TRANSET), US Department of Transportation (USDOT) Project No. 17STUNM02 is also appreciated.

ISIS Canada. (2001). Guidelines for Structural Health Monitoring [Computer File]. Canada: ISIS Canada.

Kim, J., and Lynch, J. P. (2012). Experimental analysis of vehicle-bridge interaction using a wireless monitoring system and a two-stage system identification technique. Mech. Syst. Sig. Process. 28, 3-19. doi:10.1016/j.ymssp.2011. 12.008

Ko, J. M., and Ni, Y. Q. (2005). Technology developments in structural health monitoring of large-scale bridges. Eng. Struct. 27, 1715-1725. doi:10.1016/ j.engstruct.2005.02.021

Lau, C. K., Mak, W. P. N., Wong, K. Y., Chan, W. Y. K., and Man, K. L. D. (2000). "Structural health monitoring of three cable-supported bridges in Hong Kong," in Structural Health Monitoring, 450-460.

Li, H., and Ou, J. (2016). The state of the art in SHM of cable-stayed bridges. J. Civil Struct. Monitor. 6, 43-67. doi:10.1007/s13349-015-0115-x

Li, H., Ou, J., Zhang, X., Pei, M., and Li, N. (2015). Research and practice of health monitoring for long-span bridges in the mainland of China. Smart Struct. Syst. 15, 555-576. doi:10.12989/sss.2015.15.3.555

Li, H., Ou, J., Zhao, X., Zhou, W., Li, H., Zhou, Z., et al. (2006). SHM system for the Shandong Binzhou Yellow River highway bridge. Comput. Aid. Civil Infrastruct. Eng. 21, 306-317. doi:10.1111/j.1467-8667.2006.00437.x

Li, H. N., Li, A. Q., Teng, J., Yan, W. M., He, X. F., Yi, T. H., et al. (2012). Jie gou jian kang jian ce xi tong she ji biao zhun [Design Standard for SHM Systems]. Zhong guo gong cheng jian she biao zhun hua xie hui, CECS 333-2012 (in Chinese).

Liu, M., and Frangopol, D. M. (2004). Optimal bridge maintenance planning based on probabilistic performance prediction. Eng. Struct. 26, 991-1002. doi:10.1016/j.engstruct.2004.03.003

Liu, M., and Frangopol, D. M. (2006a). Probability-based bridge network performance evaluation. J. Bridge Eng. 11, 633-641. doi:10.1061/ (ASCE)1084-0702(2006)11:5(633)

Liu, M., and Frangopol, D. M. (2006b). Optimizing bridge network maintenance management under uncertainty with conflicting criteria: life-cycle maintenance, failure, and user costs. J. Struct. Eng. 132, 1835-1845. doi:10.1061/ (ASCE)0733-9445(2006)132:11(1835)

Loh, K. J., Lynch, J. P., and Kotov, N. A. (2008). Passive wireless sensing using SWNTbased multifunctional thin film patches. Int. J. Appl. Electromag. Mech. 28, 87-94.

Longest Bridge. (2011). Guinness World Records. Available at: http://www.guinnessworldrecords.com/world-records/longest-bridge

Lynch, J. P. (2007). An overview of wireless structural health monitoring for civil structures. Philos. Trans. R. Soc. A 365, 345-372. doi:10.1098/rsta.2006.1932

Lynch, J. P., and Loh, K. J. (2006). A summary review of wireless sensors and sensor networks for structural health monitoring. Shock Vibr. Digest 38, 91-130. doi:10.1177/0583102406061499

Lynch, J. P., Sundararajan, A., Law, K. H., Kiremidjian, A. S., and Carryer, E. (2004). Embeddingdamage detection algorithmsin a wireless sensing unitforoperational power efficiency. Smart Mater. Struct. 13, 800. doi:10.1088/0964-1726/13/4/018

Mao, Z. B., Peng, M. X., Liu, J. J., Wang, J., Zhang, S. L., Qin, J. S., et al. (2013). Jian zhu gong cheng shi gong guo cheng jie gou fen xi yu jian ce ji shu gui fan [Technical Code for Construction Process Analyzing and Monitoring of Building Engineering]. Zhong hua ren min going he guo zhu fang he cheng xiang jian she bu, JGJ/T 302-2013 (in Chinese).

Moreu, F., Jo, H., Li, J., Kim, R. E., Cho, S., Kimmle, A., et al. (2014). Dynamic assessment of timber railroad bridges using displacements. J. Bridge Eng. 20, 04014114. doi:10.1061/(ASCE)BE.1943-5592.0000726

Moreu, F., Li, J., Jo, H., Kim, R. E., Scola, S., Spencer, B. F. Jr., et al. (2015). Referencefree displacements for condition assessment of timber railroad bridges. J. Bridge Eng. 21, 04015052. doi:10.1061/(ASCE)BE.1943-5592.0000805

Moreu, F., Spencer, B. F. Jr., Foutch, D. A., and Scola, S. (2017). Consequence-based management of railroad bridge networks. Struct. Infrastruct. Eng. 13, 273-286. doi:10.1080/15732479.2016.1162817 
Mufti, A. A. (2002). Structural health monitoring of innovative Canadian civil engineering structures. Struct. Health Monitor. 1, 89-103. doi:10.1177/ 147592170200100106

Nagayama, T., and Spencer, B. F. Jr. (2007). Structural Health Monitoring Using Smart Sensors. Urbana, IL: Newmark Structural Engineering Laboratory. University of Illinois at Urbana-Champaign.

Österreichische Forschungsgellschaft. (2012). Quality Assurance for Structural Maintenance, Surveillance, Checking and Assessment of Bridges and Tunnels, Monitoring of Bridges and Other Engineering Structures, RVS 13-03-01. Vienna (in German).

Ou, J. (2004). “The state-of-the-art and application of intelligent health monitoring systems for civil infrastructures in mainland of China," in Progress in Structural Engineering, Mechanics and Computation, ed. A. Zingoni (London: AA Balkema/ Taylor and Francis), 599-608.

$\mathrm{Ou}, \mathrm{J}$., and Li, H. (2010). Structural health monitoring in mainland China: review and future trends. Struct. Health Monitor. 9, 219-231. doi:10.1177/ 1475921710365269

Ou, J. P., Zhang, X. G., Li, H., Li, N., Feng, L. P., Cui, B., et al. (2016). Gong lu qiao liang jie gou an quan jian ce xi tong ji shu zhang cheng [Technical Specification of Safety Monitoring System for Highway Bridge Structure]. Zhong hua ren min gong he guo jiao tong yun shu bu, JT/T 1037-2016 (in Chinese).

Ozdagli, A. I., Gomez, J. A., and Moreu, F. (2017). Real-time reference-free displacement of railroad bridges during train-crossing events. J. Bridge Eng. 22, 04017073. doi:10.1061/(ASCE)BE.1943-5592.0001113

Pucher, J. (1995a). Urban passenger transport in the United States and Europe: a comparative analysis of public policies: Part 1. travel behaviour, urban development and automobile use. Trans. Rev. 15, 99-117. doi: $10.1080 / 01441649508716906$

Pucher, J. (1995b). Urban passenger transport in the United States and Europe: a comparative analysis of public policies: Part 2. Public transport, overall comparisons and recommendations. Trans. Rev. 15, 211-227. doi:10.1080/01441649508716913

Reinforcing Concrete Structures with Fiber Reinforced Polymers. (2007). Available at: https://www.vrodaustralia.com.au/wp-content/themes/vrod/pdf/engineering/codes_and_guides/01.pdf

Rice, J. A., and Spencer, B. F. Jr. (2008). Structural health monitoring sensor development for the Imote2 platform. In Proc. SPIE 6932, 693234. doi: $10.1117 / 12.776695$

Seth, S., Lynch, J. P., and Tilbury, D. M. (2005). "Wirelessly networked distributed controllers for real-time control of civil structures," in American Control Conference, 2005. Proceedings of the 2005 (Portland, OR: IEEE), 2946-2952.

Shi, J., Zhang, Q., and Xiang, H. (2000). "Health monitoring system of Xupu cablestayed bridge," in Proceedings of the Workshop on Research and Monitoring of Long Span Bridges (Hong Kong: The University of Hong Kong ), 150-157.

Smith, I. F. C. (2016). Studies of sensor data interpretation for asset management of the built environment. Front. Built Environ. 2:2297-3362. doi:10.3389/fbuil. 2016.00008

Spencer, B. F. Jr., and Nagarajaiah, S. (2003). State of the art of structural control. J. Struct. Eng. 129, 845-856. doi:10.1061/(ASCE)0733-9445(2003)129:7(845)
Spencer, B. F., Ruiz-Sandoval, M. E., and Kurata, N. (2004). Smart sensing technology: opportunities and challenges. Struct. Control Health Monitor. 11, 349-368. doi:10.1002/stc. 48

Structural Assessment, Monitoring and Control. (2006a). Available at: http://www. samco.org/network/index.htm

Structural Assessment, Monitoring and Control. (2006b). "Ambient vibration monitoring., case studies., certification., guidelines for structural control., guideline for the assessment of existing structures., guideline for SHM," in Report on Bridge Management., SAMCO Monitoring Glossary., SAMCO History and Events., \& Strategic Research Agenda. Available at: http://www.samco.org/ network/download_area.htm

U.S. Department of Education. (2017). Available at: https://www2.ed.gov/programs/iegpsflasf/index.html

U.S. Department of Transportation. (2012). Federal Highway Administration. Available at: https://www.fhwa.dot.gov/about/

Vemuganti, S., Ozdagli, A., Liu, B., Bajric, A., Moreu, F., Brake, M. R., et al. (2017) "Sensing and rating of vehicle-railroad bridge collision," in Dynamics of Civil Structures. Conference Proceedings of the Society for Experimental Mechanics Series, eds J. Caicedo and S. Pakzad, Vol 2 (Cham: Springer), 227-234.

Wang, J., Wu, J. H., Sun, Y. G., He, L. Z., Li, H. W., Qi, H. Z., et al. (2011). Tian jin shi qiao liang jie gou jian kang jian ce xi tong ji shu gui cheng [SHM system technical specification for bridge of Tianjin]. Tian jin shi cheng xiang jian she he jiao tong wei yuan hui, DB/T29-208-2011 (in Chinese).

Wang, M. L. (2004). "State-of-the-art applications in health monitoring," in Invited Presentation to Workshop on Basics of SHM and Optical Sensing Technologies in Civil Engineering (Taiwan: National Central University), 13-42.

Wiśniewski, D. F., Casas, J. R., and Ghosn, M. (2012). Codes for safety assessment of existing bridges-current state and further development. Struct. Eng. Int. 22, 552-561. doi:10.2749/101686612X13363929517857

Xiang, H., and Ge, Y. (2007). State-of-the-art of long-span bridge engineering in China. Front. Arch. Civil Eng. China 1:379-388. doi:10.1007/s11709-007-0051-x

Yang, Y., Li, Q., and Yan, B. (2017). Specifications and applications of the technical code for monitoring of building and bridge structures in China. Adv. Mech. Eng. 9, 168781401668427. doi:10.1177/1687814016684272

Zou, P. X., Zhang, G., and Wang, J. (2007). Understanding the key risks in construction projects in China. Int. J. Project Manage. 25, 601-614. doi:10.1016/ j.ijproman.2007.03.001

Conflict of Interest Statement: The authors declare that the research was conducted in the absence of any commercial or financial relationships that could be construed as a potential conflict of interest.

Copyright (C) $2018 \mathrm{Moreu}, \mathrm{Li}, \mathrm{Li}$ and Zhang. This is an open-access article distributed under the terms of the Creative Commons Attribution License (CC BY). The use, distribution or reproduction in other forums is permitted, provided the original author(s) and the copyright owner are credited and that the original publication in this journal is cited, in accordance with accepted academic practice. No use, distribution or reproduction is permitted which does not comply with these terms. 